\title{
Combination of GHRH antagonists and docetaxel shows experimental effectiveness for the treatment of triple-negative breast cancers
}

\author{
S. SEITZ ${ }^{1-3}$, F.G. RICK ${ }^{2}$, A.V. SCHALLY ${ }^{2,3}$, A. TRESZL ${ }^{2,3}$, F. HOHLA ${ }^{2-4}$, L. SZALONTAY ${ }^{2}$, \\ M. ZARANDI ${ }^{2,3}$, O. ORTMANN ${ }^{1}$, J.B. ENGEL ${ }^{1}$ and S. BUCHHOLZ ${ }^{1-3}$
}

\begin{abstract}
${ }^{1}$ Department of Gynecology and Obstetrics, University Medical Center Regensburg, 93053 Regensburg, Germany;
${ }^{2}$ Endocrine, Polypeptide and Cancer Institute, Veterans Affairs Medical Center and South Florida Veterans Affairs

Foundation for Research and Education, Miami, FL 33125; ${ }^{3}$ Department of Pathology and

Divisions of Hematology/Oncology and Endocrinology, Department of Medicine, University of Miami, Miller School of Medicine, Miami, FL 33125, USA; ${ }^{4} 3$ rd Medicine with Haematology, Oncology,

Rheumatology and Infectiology, Private Medical University of Salzburg, Salzburg, Austria
\end{abstract}

Received March 11, 2013; Accepted April 9, 2013

DOI: 10.3892/or.2013.2435

\begin{abstract}
In preclinical studies, antagonists of growth hormone-releasing hormone $(\mathrm{GHRH})$ have demonstrated inhibitory effects on the growth of various types of cancers expressing the pituitary type of GHRH receptors (pGHRH-R) and/or its active splice variant 1 (SV1). In this study, we investigated the effectiveness of the treatment of MDA-MB231 human triple-negative breast cancer (TNBC) with GHRH antagonist JMR-132 alone or in combination with docetaxel. Receptor expression in the MDA-MB-231 human breast cancer cell line was evaluated by reverse transcriptionpolymerase chain reaction (RT-PCR). Cell viability assays were performed on MDA-MB-231 cells treated with JMR-132, docetaxel or in combination. For studies in vivo, a subcutaneous nude mouse xenograft model was used. JMR-132 was administered s.c. at a dose of $10 \mu \mathrm{g} /$ day and docetaxel at a dose of $10 \mathrm{mg} / \mathrm{kg}$ i.p. given on day 1 and 5 . Similar regimens were used for the combination of both substances. At the end of the experiment, an mRNA-based human cancer pathway array including 84 major genes was performed on the tumor tissue of mice treated with JMR-132 to elucidate the mechanism of action of GHRH antagonists in vivo. The in vitro proliferation studies revealed that JMR-132 and docetaxel decreased the cell viability in a dose-dependent manner. The combination of both treatments produced a significantly greater inhibition of cell viability compared to the single agents. Treatment of nude
\end{abstract}

Correspondence to: Dr S. Seitz, Department of Gynecology and Obstetrics, University Medical Center Regensburg, Landshulter Strasse 65, 93053 Regensburg, Germany

E-mail: stephan_seitz@gmx.de

Key words: triple-negative breast cancer, growth hormone-releasing hormone antagonist, splice variant 1 mice bearing MDA-MB-231 xenografts with JMR-132 and docetaxel significantly $(\mathrm{p}<0.05)$ inhibited tumor growth by 46 and $50 \%$, respectively. Treatment with the combination of JMR-132 and docetaxel led to an inhibition of tumor volume by $71.6 \%(p<0.001)$. Polymerase chain reaction array analysis revealed that JMR-132 interacts with signal transduction pathways involved in proliferation, apoptosis and angiogenesis. Our results suggest that GHRH antagonists in combination with taxanes may enhance the efficacy of treatment for patients with TNBC expressing the SV1 and/or the pGHRH receptor.

\section{Introduction}

Breast cancer is the most frequently diagnosed cancer in women. Triple-negative breast cancer (TNBC) is a distinct subtype lacking the expression of receptors for estrogen (ER), progesterone (PR) and HER2/neu. Systemic treatment options are limited to chemotherapy. TNBC accounts for $10-17 \%$ of all breast cancers and is burdened by a poor prognosis (1-3). Thus, the development of novel therapeutic strategies is of paramount importance. Growth hormone-releasing hormone (GHRH) is a peptide hormone found in the hypothalamus (4), which stimulates growth hormone secretion from the pituitary gland and thus IGF-1 secretion by the liver. Various antagonists of GHRH were synthesized in our laboratory including JMR-132. GHRH antagonists suppress the release of GH from the pituitary resulting in an inhibition of IGF-I production by the liver. However, recent studies have shown an ectopic expression of GHRH and its receptors in various benign tissues (5-7), but more importantly in various types of cancers suggesting that GHRH acts as a local tumor growth factor via an autocrine/paracrine loop in these tissues (8-20).

Several preclinical in vitro studies where the hypothalamic/pituitary/hepatic axis is clearly excluded, underlined this hypothesis of an autocrine/paracrine function. Additional studies demonstrated the existence of several splice variants 
of the pituitary GHRH receptor (pGHRH-R) of which splice variant 1 (SV 1) is a fully functional receptor (21-24).

GHRH receptors and its splice variants are present in surgical specimens of breast cancers. Our group demonstrated recently, that the pGHRH-R is expressed in $25 \%$ and the SV1 receptor in $70 \%$ of TNBC tissue samples. Additionally, $80 \%$ of these samples expressed GHRH, suggesting the presence of an autocrine/paracrine growth stimulatory loop (25). In HCC1806 human TNBC cells, MAP-kinases ERK-1/2 were activated by treatment with GHRH, and GHRH stimulated proliferation of MDA-MB-231 human breast cancer cell lines through activation of the MAP-kinase phosphorylation pathway via Ras/Raf/MEK/ERK $(26,27)$.

Taxanes such as paclitaxel and docetaxel have been observed to impinge upon several signaling pathways to bring about cell cycle arrest and apoptosis. Some of the most common changes after treatment are Bcl-2 phosphorylation and the activation of mitotic spindle assembly checkpoint $(28,29)$. This class of substances is now well established as one of the most efficacious for the treatment of early and metastatic breast cancer of all molecular subtypes.

We previously demonstrated that combined treatment with GHRH antagonist JMR-132 and docetaxel led to a potentiation of the antiproliferative effect of both compounds in human MX-1 breast cancers xenografted into nude mice (30).

To further explore this novel promising treatment approach, the combination of a GHRH antagonist and a taxane was investigated in in vitro and in vivo models of TNBC, given the dismal prognosis of this subgroup of breast cancers.

\section{Materials and methods}

Peptides and chemicals. The GHRH antagonist JMR-132 was synthesized in our laboratory. For daily injection, JMR-132 was dissolved in $0.1 \%$ dimethyl sulfoxide (DMSO) in $10 \%$ aqueous propylene glycol solution (vehicle solution). For in vitro experiments, JMR-132 was dissolved in DMSO and diluted further with PBS to the used concentration not exceeding 0.1\% DMSO. Docetaxel (DOC) ready-to-use vials from Sanofi-Aventis were used for the experiments and diluted according to the manufacturer's instructions.

Cell lines and animals. The triple negative breast cancer cell line MDA-MB-231 was obtained from the American Type Culture Collection (Manassas, VA, USA). Cells were cultured in Dulbecco's modified Eagle's medium (DMEM) supplemented with $10 \%$ fetal bovine serum (FBS) and penicillin/streptomycin at $37^{\circ} \mathrm{C}$ and $5 \% \mathrm{CO}_{2}$ atmosphere.

Female athymic nude mice (Ncr nu/nu) (5-6 weeks old) were obtained from the National Cancer Institute (NCI, Bethesda, MD, USA). The animals were housed in sterile cages under laminar flow hoods in a temperature-controlled room with a 12-h light/12-h dark schedule. They were fed autoclaved chow and water ad libitum. The Institutional Animal Care and Use Committee reviewed the protocols of the animal experiments and granted full approval.

Reverse transcription and RT-PCR. Total RNA was isolated and DNase-treated using the Macherey-Nagel NucleoSpin ${ }^{\circledR}$ kit according to the manufacturer's instructions (Macherey-Nagel,
Düren, Germany). The yield and the quality of RNA samples were determined spectrophotometrically using $260 \mathrm{~nm}$, and 260/280 and 260/230 $\mathrm{nm}$ ratio. Two micrograms of RNA from the sample was reverse transcribed into cDNA by QuantiTect reverse transcription kit (Qiagen, Hilden, Germany) in a final volume of $40 \mu \mathrm{l}$. We evaluated the mRNA expression of human pituitary GHRH receptor (pGHRH-R) and SV1 of GHRH-R as previously reported (31). The probe and primers for $\mathrm{pGHRH}-\mathrm{R}$ and sense and antisense specific primers for SV1 were described previously (23).

All real-time PCR reactions were performed using the iCycler $\mathrm{iQ}^{\mathrm{TM}}$ Real-Time PCR detection system (Bio-Rad, Hercules, CA, USA). All thermal cycling conditions were described previously (18). All samples were run in triplicate, and each well of the PCR reaction contained $25 \mu 1$ as a final volume including $2 \mu \mathrm{l}$ of cDNA, $200 \mathrm{nM}$ of the gene-specific primers and $400 \mathrm{nM}$ of probes. $\mathrm{iQ}^{\mathrm{TM}}$ Supermix was used in the PCR reactions for $\mathrm{pGHRH}-\mathrm{R}$ and $\mathrm{iQ}^{\mathrm{TM}} \mathrm{SYBR}-\mathrm{Green}$ Supermix (both from Bio-Rad) for SV1. The efficiencies of all primers (Invitrogen Life Technologies, Carlsbad, CA, USA) and the probe (Integrated DNA Technologies, Coralville, IA, USA) were tested prior to the experiments and were efficient in the range of $95-105 \%$. Normal human pituitary was used as the positive control, and human $\beta$-actin as the housekeeping gene. Negative samples were run in each reaction consisting of no-RNA in the reverse transcriptase reaction and no-cDNA in the PCR reaction.

Cell viability assays. For cell viability studies, 5,000 cells/well were seeded in a 96-well plate in $100 \mu \mathrm{l}$ medium. After $24 \mathrm{~h}$, the culture medium was replaced by JMR-132 at different concentrations $(0.1,1,10 \mu \mathrm{M})$ and in other studies by JMR-132 $(5 \mu \mathrm{M})$, DOC $(1.28$ or $0.635 \mathrm{nM})$ or the combination of JMR-132 and DOC at different concentrations. The cells were then incubated for $72 \mathrm{~h}$ in a humidified atmosphere at $37^{\circ} \mathrm{C}$. The effect of the agents on cell proliferation was evaluated using the MTS assay (CellTiter 96 Aqueous One Solution cell proliferation assay; Promega Corporation, Madison, WI, USA) according to the manufacturer's instructions. Absorbance was measured at $550 \mathrm{~nm}$ using an enzyme-linked immunosorbent assay (ELISA) plate reader. All experiments were performed in hexaplicates and repeated 3 times.

In vivo experiments. For the animal experiments, $10 \times 10^{6}$ MDA-MB-231 cells/mouse were injected into the flanks of 4 female nude mice. The resulting tumors were harvested and minced into $\sim 3-\mathrm{mm}^{3}$ pieces and transplanted into both flanks of each female nude mouse using a mini trocar. The experiment was initiated when the MDA-MB-231 tumors had reached a volume of $\sim 110 \mathrm{~mm}^{3}$. Mice were divided into 4 experimental groups: control (animals $\mathrm{n}=10$; tumors $\mathrm{n}=15), \mathrm{JMR}-132(10 \mu \mathrm{g}$ / day) (animals $\mathrm{n}=8$; tumors $\mathrm{n}=10)$, DOC $(10 \mathrm{mg} / \mathrm{kg}$ on day 1 and 5, i.p.) (animals $n=6$; tumors $n=10$ ), and a combination of DOC $(10 \mathrm{mg} / \mathrm{kg}$ on day 1 and 5, i.p.) and JMR-132 (10 $\mu \mathrm{g} /$ day) (animals $n=8$, tumors $n=13$ ). The weight of the animals was measured weekly.

Tumor volume (length $\mathrm{x}$ width $\mathrm{x}$ height $\mathrm{x}$ 0.5236) was measured weekly, and tumor doubling time was calculated at the end of the study using the formula: Study duration/(log final tumor volume - $\log$ initial tumor volume)/ $\log 2$. 
At the end of the experiment, mice were sacrificed under anesthesia, tumors were excised, snap frozen at $-70^{\circ} \mathrm{C}$ for further experiments and a full necropsy was performed.

Human cancer PathwayFinder PCR array. Quantitative mRNA expression analysis of 84 genes representative of the major biological pathways involved in transformation and tumorigenesis was performed using the Human Cancer PathwayFinder $^{\mathrm{TM}}$ RT $^{2}$ Profiler $^{\mathrm{TM}}$ PCR array (PAHS-033A; Qiagen, Valencia, CA, USA). RNA was extracted and DNAsetreated using the Macherey-Nagel NucleoSpin kit from 6 representative tumors grown in the nude mice 3 tumors from the control and 3 tumors from the animals treated with JMR-132). The yield and the quality of RNA samples, synthesis of cDNA and real-time RT-PCT arrays were performed as previously described (32). Real-time PCR reactions were performed using the $\mathrm{iCycler}_{\mathrm{iQ}} \mathrm{Q}^{\mathrm{TM}}$ Real-Time PCR detection system. All genes represented by the array showed a single peak on the melting curve characteristic to the specific products. Data analysis of gene expression was performed as previously described (9). Briefly, using Excel-based PCR array data analysis software provided by the manufacturer, fold-changes in gene expression were calculated using the $\Delta \Delta \mathrm{Ct}$ method, and 5 stably expressed housekeeping genes (B2M, HPRT1, RPL13A, GAPDH and ACTB) were used for normalization of the results.

Statistical analysis. Data are expressed as means $\pm \mathrm{SE}$. One-way ANOVA followed by Bonferroni t-test or a two-tailed Student's t-test was used where appropriate, and significance was accepted at $\mathrm{p}<0.05$.

\section{Results}

Receptor expression for $p G H R H-R$ and SV1. Expression of mRNA of SV1 was detected in the MDA-MB-231 cell line (Ct value 32.6) by real-time RT-PCR. However the expression of the pGHRH-R could not be determined. For the positive control (pituitary) the $\mathrm{Ct}$ value for pGHRH-R was 20.5 and for SV1, 33.3.

Effect of GHRH antagonist JMR-132 and DOC on the viability of $M D A-M B-231$ human breast cancer cells in vitro. In the first experiment, we determined the effect of GHRH antagonist JMR-132 at different concentrations on the MDA-MB-231 cell line in the proliferation assays. A significant $(\mathrm{p}<0.05)$ dose-dependent inhibition of cell viability was noted when compared to the controls. In the second experiment, we evaluated the combination of JMR-132 and DOC and demonstrated a significant $(\mathrm{p}<0.05)$ dose-dependent inhibition of cell viability at different concentrations of DOC. The combination of both substances led to an even greater inhibition of cell viability compared to treatment with the single agents. This effect became statistically significant at a combination dose of $5 \mu \mathrm{M}$ JMR-132 and 1.28 nM DOC (Figs. 1 and 2).

Effect of GHRH antagonist JMR-132 and DOC on the growth of $M D A-M B-231$ human breast cancer cell xenografted tumors in nude mice. The tumor volume was significantly $(\mathrm{p}<0.05)$ reduced by $46 \%$ following treatment with JMR-132

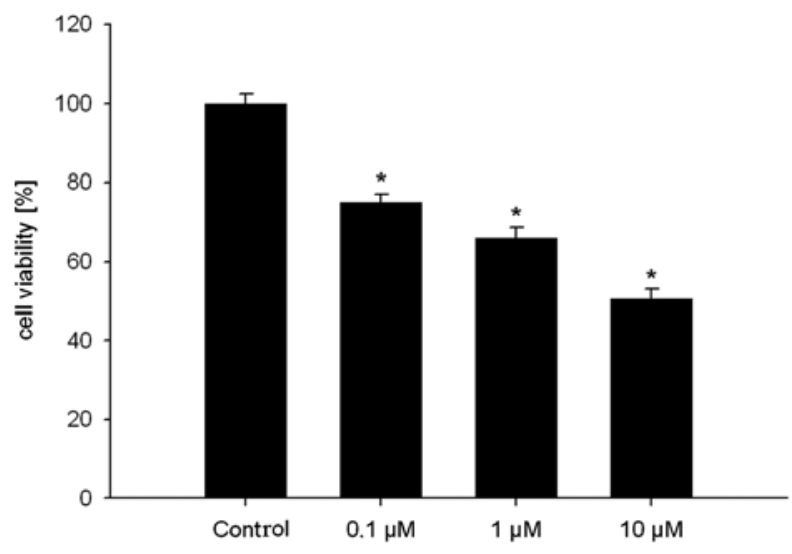

Figure 1. Proliferation assays of MDA-MB-231 cells treated with different concentrations of the GHRH antagonist JMR-132. Error bars, SE; ${ }^{*} \mathrm{p}<0.05$ compared to control.

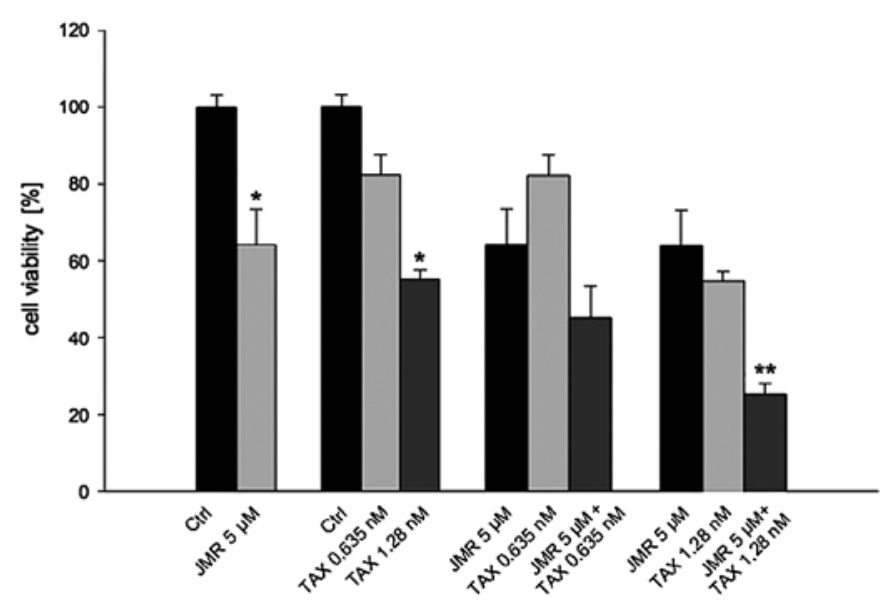

Figure 2. In vitro proliferation assay of MDA-MB-231 cells. Cells were treated with the GHRH antagonist JMR-132 and/or docetaxel (TAX) at different concentrations. Error bars, SE; ${ }^{*} \mathrm{p}<0.05$ compared to black bars; *** $\mathrm{p}<0,05$ compared to both bars.

at a dose of $10 \mu \mathrm{g} /$ day s.c., when compared to the controls at the end of the study (Fig. 3). Additionally, JMR-132 significantly $(\mathrm{p}<0.05)$ increased the tumor doubling time (Table I). When nude mice bearing MDA-MB-231 tumors received DOC as a monotherapy, tumor growth was inhibited by $50 \%$ $(p<0.05$, Fig. 3) as compared to the control group, and the tumor doubling time was significantly prolonged compared to the controls $(\mathrm{p}<0.05$, Table I).

Combined treatment with JMR-132 and DOC resulted in significant tumor inhibition $(\mathrm{p}<0.001)$ after 14 days, and the inhibition remained significant until the end of the experiment when compared to the controls. A significant reduction in tumor volume by $70 \%$ was achieved in this group (Fig. 3). The combination treatment of DOC and JMR-132 was significantly more potent $(\mathrm{p}<0.05)$ with respect to inhibition of the tumor volume when compared to the monotherapy groups. The tumor doubling time was also significantly $(\mathrm{p}<0.05)$ extended when compared to the other groups (Fig. 3 and Table I). 


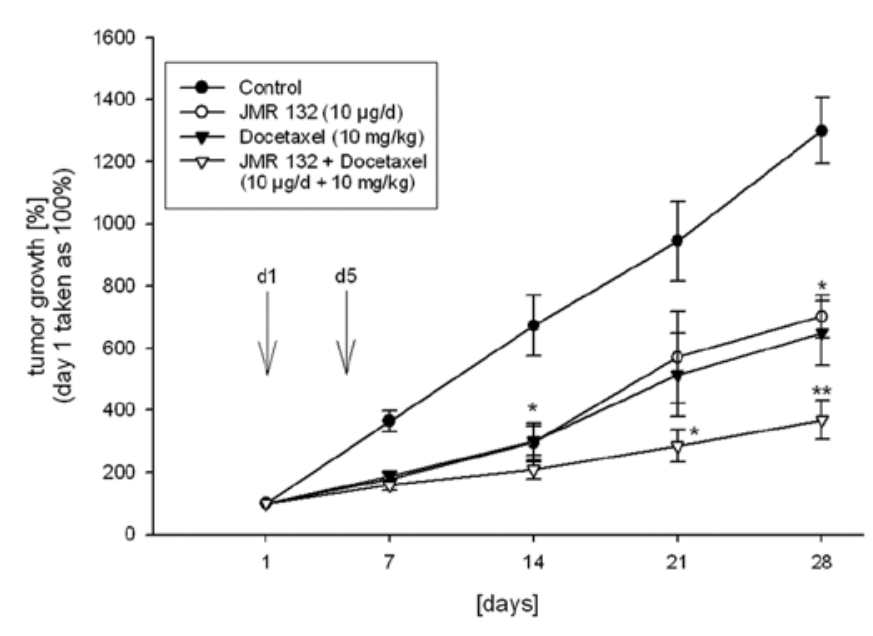

Figure 3. Inhibition of tumor growth in vivo. Error bars, SE. Arrows indicate i.p. injections of docetaxel (DOC) $(10 \mathrm{mg} / \mathrm{kg})$. JMR-132 was administered s.c. daily, docetaxel was administered i.p. *Day 14: ctrl vs. JMR-132, DOC, JMR-132 + DOC; p<0.05, respectively. *Day 21: ctrl vs. JMR-132 + DOC; p<0.05. "Day 28: ctrl vs. JMR-132, DOC; p<0.05, respectively. ${ }^{* *}$ Day 28: JMR-132 + DOC vs. all other groups; $\mathrm{p}<0.05$.

Toxicity. No signs of drug-induced toxicity were observed in any of the mouse groups, as reflected by no differences in body and organ weights between the treated groups and the control animals.

Effect of GHRH antagonist JMR-132 on expression of genes related to apoptosis, angiogenesis and metastasis. The PCR array used contains 84 unique genes related to signal transduction, cell cycle and apoptosis. All genes represented by the array showed a single peak on the melting curve characteristic to the specific products. Fifteen genes in the MDA-MB-231 xenografts showed a significant change in mRNA expression after treatment with JMR-132 compared to the controls (Table II). Upregulated genes were found to belong to the TNF ligand family FASLG, LTA, TNFSF10, CD70, TNFSF8 (5.28-, 10.56-, 2.00-, 9.19-, 7.46-fold increases; $\mathrm{p}<0.05$ for all). Significant transcriptional suppression of angiogenesis-related gene ANGPT1 (2.93-fold decrease, p<0.05) was observed. Significant alterations in transcriptional gene expression involved in apoptosis or cell death were detected for BCL2 (3.48-fold decrease, $\mathrm{p}<0.05$ ), and HRK, CASP14, CASP4, CASP5, DAPK, CIDEA (14.93-, 14.93-, 2.3-, 10.53-, 3.03-, 9.17 -fold increases, $\mathrm{p}<0.05$ for all). Changes in the mRNA levels for molecules related to invasion and metastasis were found for MMP2 (2.07-fold decrease, $\mathrm{p}<0.05)$ and TWIST1 (2.73-fold increase, $\mathrm{p}<0.05)$.

\section{Discussion}

Novel therapeutic strategies for the treatment of many types of cancers are based on agents targeting cell signaling pathways that interacting with the cell cycle, apoptosis, proliferation or angiogenesis. New therapeutic agents such as trastuzumab and lapatinib have been clinically used with great success for years.

Previously, we found that the pGHRH-R is expressed in $25 \%$ and SV1 in $70 \%$ of TNBC tissue samples, and in $80 \%$
Table I. Tumor doubling time calculated at the end of the study.

\begin{tabular}{lcc}
\hline & $\begin{array}{c}\text { Tumor growth }(\%) \\
\text { on day } 28\end{array}$ & $\begin{array}{c}\text { Tumor doubling } \\
\text { times (days) }\end{array}$ \\
\hline Control & $1,299 \pm 106.96$ & $7.90 \pm 0.47$ \\
JMR-132 & $701 \pm 69.8$ & $10.26 \pm 0.52^{\mathrm{b}}$ \\
Docetaxel & $649 \pm 103.26$ & $12.32 \pm 1.86^{\mathrm{b}}$ \\
JMR-132 + docetaxel & $369 \pm 62.51^{\mathrm{a}}$ & $19.52 \pm 1.02^{\mathrm{c}}$
\end{tabular}

Tumor doubling time was calculated at the end of the study using the formula: Study duration/(log final tumor volume - log initial tumor volume $) / \log 2$. Values are the means \pm SE. ${ }^{a} J M R-132+$ docetaxel vs. all other groups; $\mathrm{p}<0.05$. bJMR-132 or docetaxel vs. control; $\mathrm{p}<0.05$ ${ }^{\mathrm{c}} \mathrm{JMR}-132+$ docetaxel vs. all other groups; $\mathrm{p}<0.05$.

of these samples GHRH is expressed (25). Various findings suggest that GHRH acts as a growth factor in GHRH receptorpositive malignancies, which may represent an attractive therapeutic target for antagonists of GHRH (10-13,15-19).

Since chemotherapy is the only therapeutic option for TNBC, GHRH antagonists could provide a novel targeted approach for this subgroup of breast cancers.

In the present study we demonstrated the presence of SV1 but not pGHRH-R in the human triple-negative breast cancer cell line MDA-MB-231 and the antitumoral effect of the GHRH antagonist JMR-132. This finding provides strong evidence for the important role of SV1 as a functional receptor. Treatment with JMR-132 significantly inhibited cell proliferation in a dose-dependent manner in MDA-MB-231 human breast cancers in vitro. JMR also demonstrated antitumor activity in vivo. The in vivo study also revealed that GHRH antagonist JMR-132 interacts with various signal transduction pathways involved in proliferation, apoptosis and angiogenesis. In TNBC, the MAPK and the AKT signal transduction pathways have been found to be significantly overactivated $(33,34)$. These two pathways induce a variety of cellular events, of which many are connected to proliferation and resistance to apoptosis. Notably, targeting the GHRH signal transduction pathway also resulted in the suppression of genes inducing proliferation and resistance to apoptosis. Thus, targeting the GHRH-receptor may also result in a synergistic effect in combination with novel antitumor agents, such as AKT and ERK inhibitors and not only with chemotherapeutic agents as demonstrated in our study.

Docetaxel is a chemotherapeutic agent frequently used in the treatment of breast cancers. Furthermore, taxanes have been favorably used in combination with monoclonal antibodies and small-molecule agents such as trastuzumab or lapatinib. Therefore, taxane could be likely candidates for combination therapy with GHRH antagonists. Accordingly, the present study showed that a combination of DOC with JMR-132 potentiated the antitumor effect in vitro and in vivo as compared to each substance alone.

In conclusion, this investigation demonstrated that GHRH antagonists are effective for the treatment of SV1-positive TNBC and can be combined with taxane-based chemotherapy. As in our study and various other studies, GHRH antagonists 
Table II. Modulated genes with at least a 2-fold change relative to the untreated control after treatment of MDA-MB-231 xenografts with the GHRH antagonist JMR-132.

\begin{tabular}{|c|c|c|c|}
\hline Name of gene & Gene symbol & Accession no. & Fold change $^{\mathrm{a}}$ \\
\hline Angiopoietin 1 & ANGPT1 & NM_001146 & -2.93 \\
\hline Antigen identified by monoclonal antibody Ki-67 & MKI67 & NM_002417 & -2.69 \\
\hline B-cell CLL/lymphoma 2 & BCL2 & NM_000633 & -3.48 \\
\hline Baculoviral IAP repeat containing 8 & BIRC8 & NM_033341 & 4.29 \\
\hline Bcl2-like 10 & BCL2L10 & NM_020396 & 3.03 \\
\hline Breast cancer 1 , early onset & BRCA1 & NM_007294 & -2.73 \\
\hline Caspase 14 & CASP14 & NM_012114 & 14.93 \\
\hline Caspase 4 & CASP4 & NM_001225 & 2.30 \\
\hline Caspase 5 & CASP5 & NM_004347 & 10.53 \\
\hline CD40 ligand & CD40LG & NM_000074 & 5.66 \\
\hline CD70 molecule & CD70 & NM_001252 & 9.19 \\
\hline Cell death-inducing DFFA-like effector a & CIDEA & NM_001279 & 9.17 \\
\hline Cullin 1 & CUL1 & NM_003592 & -2.18 \\
\hline Cyclin B2 & CCNB2 & NM_004701 & -2.04 \\
\hline Cyclin D2 & CCND2 & NM_001759 & 12.77 \\
\hline Death-associated protein kinase 1 & DAPK1 & NM_004938 & 3.03 \\
\hline Fas ligand (TNF superfamily, member 6) & FASLG & NM_000639 & 5.28 \\
\hline Fibroblast growth factor receptor 2 & FGFR2 & NM_000141 & 7.21 \\
\hline Granzyme A & GZMA & NM_006144 & 3.14 \\
\hline Harakiri, BCL2 interacting protein & HRK & NM_003806 & 14.93 \\
\hline Integrin, $\beta 3$ & ITGB3 & NM_000212 & -3.87 \\
\hline Interleukin 8 & IL8 & NM_000584 & 3.13 \\
\hline Lymphotoxin $\alpha$ (TNF superfamily, member 1$)$ & LTA & NM_000595 & 10.56 \\
\hline MAD2 mitotic arrest deficient-like 1 (yeast) & MAD2L1 & NM_002358 & -3.08 \\
\hline Matrix metallopeptidase 1 & MMP1 & NM_002421 & 4.44 \\
\hline Matrix metallopeptidase 2 & MMP2 & NM_004530 & -2.07 \\
\hline Platelet-derived growth factor $\beta$ polypeptide & PDGFB & NM_002608 & 2.55 \\
\hline Serpin peptidase inhibitor, clade B (ovalbumin), member 5 & SERPINB5 & NM_002639 & -2.56 \\
\hline TEK tyrosine kinase, endothelial & TEK & NM_000459 & 2.54 \\
\hline Tumor necrosis factor & TNF & NM_000594 & 6.28 \\
\hline Tumor necrosis factor & TNF & NM_000594 & 16.00 \\
\hline Tumor necrosis factor (ligand) superfamily, member 10 & TNFSF10 & NM_003810 & 2.00 \\
\hline Tumor necrosis factor (ligand) superfamily, member 8 & TNFSF8 & NM_001244 & 7.46 \\
\hline Tumor necrosis factor receptor superfamily, member 9 & TNFRSF9 & NM_001561 & 9.19 \\
\hline Tumor protein $\mathrm{p} 53$ & TP53 & NM_000546 & -2.19 \\
\hline Twist homolog 1 & TWIST1 & NM_000474 & 2.73 \\
\hline
\end{tabular}

Multiple genes related to cell proliferation, apoptosis, cell cycle, angiogenesis, invasion and metastasis were evaluated for expression using real-time PCR via $\mathrm{RT}^{2}$ Profiler ${ }^{\mathrm{TM}}$ PCR array system. The table lists the genes of interest evaluated and their fold increase or decrease in MDA-MB-231 human breast cancer xenografts treated with GHRH antagonist JMR-132 (10 $\mu \mathrm{g} /$ day $)$. Data represent the fold differences in

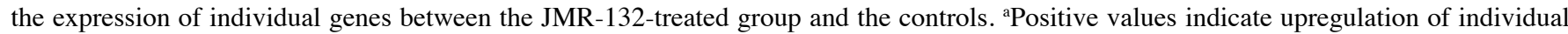
genes, while negative values indicate downregulation. Three experiments were run for each study group. The data were evaluated by two-tailed Student's t-test. Bold print depicts significant changes $(\mathrm{p}<0.05)$.

displayed no toxic side effects. Thus, they should be assessed in combination with taxanes in phase I trials for the treatment of patients with TNBC expressing the SV1 and/or pGHRH receptor.

\section{Acknowledgements}

This work was supported in part by a grant from the American Urological Association (AUA) Foundation Research Scholars 
Program and the AUA Southeastern Section (to F.G.R.). Our study was also supported by the Medical Research Service of the Veterans Affairs, Departments of Pathology and Medicine, Division of Hematology/Oncology of the Miller Medical School, University of Miami, and South Florida Veterans Affairs Foundation for Research and Education (all to A.V.S.).

\section{References}

1. Carey LA, Dees EC, Sawyer L, et al: The triple negative paradox: primary tumor chemosensitivity of breast cancer subtypes. Clin Cancer Res 13: 2329-2334, 2007.

2. Dent R, Trudeau M, Pritchard KI, et al: Triple-negative breast cancer: clinical features and patterns of recurrence. Clin Cancer Res 13: 4429-4434, 2007.

3. Tischkowitz M, Brunet JS, Bégin LR, et al: Use of immunohistochemical markers can refine prognosis in triple negative breast cancer. BMC Cancer 7: 134, 2007.

4. Schally AV, Steelman SL and Bowers CY: Effect of hypothalamic extracts on release of growth hormone in vitro. Proc Soc Exp Biol Med 119: 208-212, 1965.

5. Rick FG, Schally AV, Block NL, et al: Antagonists of growth hormone-releasing hormone (GHRH) reduce prostate size in experimental benign prostatic hyperplasia. Proc Natl Acad Sci USA 108: 3755-3760, 2011.

6. Kiaris H, Chatzistamou I, Papavassiliou AG and Schally AV: Growth hormone-releasing hormone: not only a neurohormone. Trends Endocrinol Metab 22: 311-317, 2011.

7. Rick FG, Szalontay L, Schally AV, et al: Combining growth hormone-releasing hormone antagonist with luteinizing hormone-releasing hormone antagonist greatly augments benign prostatic hyperplasia shrinkage. J Urol 187: 1498-1504, 2012.

8. Bagnato A, Moretti C, Ohnishi J, Frajese G and Catt KJ: Expression of the growth hormone-releasing hormone gene and its peptide product in the rat ovary. Endocrinology 130 : 1097-1102, 1992.

9. Rick FG, Schally AV, Szalontay L, et al: Antagonists of growth hormone-releasing hormone inhibit growth of androgen-independent prostate cancer through inactivation of ERK and Akt kinases. Proc Natl Acad Sci USA 109: 1655-1660, 2012.

10. Busto R, Schally AV, Braczkowski R, et al: Expression of mRNA for growth hormone-releasing hormone and splice variants of GHRH receptors in human malignant bone tumors. Regul Pept 108: 47-53, 2002.

11. Busto R, Schally AV, Varga JL, et al: The expression of growth hormone-releasing hormone (GHRH) and splice variants of its receptor in human gastroenteropancreatic carcinomas. Proc Natl Acad Sci USA 99: 11866-11871, 2002.

12. Chatzistamou I, Schally AV, Kiaris H, et al: Immunohistochemical detection of GHRH and its receptor splice variant 1 in primary human breast cancers. Eur J Endocrinol 151: 391-396, 2004.

13. Engel JB, Keller G, Schally AV, et al: Inhibition of growth of experimental human endometrial cancer by an antagonist of growth hormone-releasing hormone. J Clin Endocrinol Metab 90: 3614-3621, 2005.

14. Frohman LA and Szabo M: Ectopic production of growth hormone-releasing factor by carcinoid and pancreatic islet tumors associated with acromegaly. Prog Clin Biol Res 74: 259-271, 1981.

15. Garcia-Fernandez MO, Schally AV, Varga JL, Groot K and Busto R: The expression of growth hormone-releasing hormone $(\mathrm{GHRH})$ and its receptor splice variants in human breast cancer lines; the evaluation of signaling mechanisms in the stimulation of cell proliferation. Breast Cancer Res Treat 77: 15-26, 2003 .
16. Guo J, Schally AV, Zarandi M, Varga J and Leung PC: Antiproliferative effect of growth hormone-releasing hormone (GHRH) antagonist on ovarian cancer cells through the EGFR-Akt pathway. Reprod Biol Endocrinol 8: 54, 2010.

17. Kahán Z, Arencibia JM, Csernus VJ, et al: Expression of growth hormone-releasing hormone $(\mathrm{GHRH})$ messenger ribonucleic acid and the presence of biologically active GHRH in human breast, endometrial, and ovarian cancers. J Clin Endocrinol Metab 84: 582-589, 1999.

18. Schally A and Varga, JL: Antagonists of growth hormonereleasing hormone. Comb Chem High Throughput Screen 9: 163-170, 2006.

19. Schally AV, Comaru-Schally AM, Nagy A, et al: Hypothalamic hormones and cancer. Front Neuroendocrinol 22: 248-291, 2001.

20. Schally AV, Varga JL and Engel JB: Antagonists of growthhormone-releasing hormone: an emerging new therapy for cancer. Nat Clin Pract Endocrinol Metab 4: 33-43, 2008.

21. Barabutis N, Siejka A, Schally AV, Block NL, Cai R and Varga L: Activation of mitogen-activated protein kinases by a splice variant of GHRH receptor. J Mol Endocrinol 44: 127-134, 2010.

22. Barabutis N, Tsellou E, Schally AV, Kouloheri S, Kalofoutis A and Kiaris H: Stimulation of proliferation of MCF-7 breast cancer cells by a transfected splice variant of growth hormone-releasing hormone receptor. Proc Natl Acad Sci USA 104: 5575-5579, 2007.

23. Havt A, Schally AV, Halmos G, et al: The expression of the pituitary growth hormone-releasing hormone receptor and its splice variants in normal and neoplastic human tissues. Proc Natl Acad Sci USA 102: 17424-17429, 2005.

24. Rekasi Z, Czompoly T, Schally AV and Halmos G: Isolation and sequencing of cDNAs for splice variants of growth hormonereleasing hormone receptors from human cancers. Proc Natl Acad Sci USA 97: 10561-10566, 2000

25. Köster F, Engel JB, Schally AV, et al: Triple-negative breast cancers express receptors for growth hormone-releasing hormone (GHRH) and respond to GHRH antagonists with growth inhibition. Breast Cancer Res Treat 116: 273-279, 2009.

26. Pombo CM, Zalvide J, Gaylinn BD and Dieguez C: Growth hormone-releasing hormone stimulates mitogen-activated protein kinase. Endocrinology 141: 2113-2119, 2000.

27. Siriwardana G, Bradford A, Coy D and Zeitler P: Autocrine/paracrine regulation of breast cancer cell proliferation by growth hormone releasing hormone via Ras, Raf, and mitogen-activated protein kinase. Mol Endocrinol 20: 2010-2019, 2006.

28. Berchem GJ, Bosseler M, Mine N and Avalosse B: Nanomolar range docetaxel treatment sensitizes MCF-7 cells to chemotherapy induced apoptosis, induces G2M arrest and phosphorylates bcl-2. Anticancer Res 19: 535-540, 1999.

29. Lavelle F, Bissery MC, Combeau C, Riou JF, Vrignaud P and André S: Preclinical evaluation of docetaxel (Taxotere). Semin Oncol 22: 3-16, 1995.

30. Buchholz S, Schally AV, Engel JB, et al: Potentiation of mammary cancer inhibition by combination of antagonists of growth hormone-releasing hormone with docetaxel. Proc Natl Acad Sci USA 104: 1943-1946, 2007.

31. Kovács M, Schally AV, Hohla F, et al: A correlation of endocrine and anticancer effects of some antagonists of GHRH. Peptides 31: 1839-1846, 2010.

32. Rick FG, Schally AV, Block NL, et al: LHRH antagonist Cetrorelix reduces prostate size and gene expression of proinflammatory cytokines and growth factors in a rat model of benign prostatic hyperplasia. Prostate 71: 736-747, 2011.

33. Umemura S, Yoshida S, Ohta Y, Naito K, Osamura RY and Tokuda Y: Increased phosphorylation of Akt in triple-negative breast cancers. Cancer Sci 98: 1889-1892, 2007.

34. Eralp Y, Derin D, Ozluk Y, et al: MAPK overexpression is associated with anthracycline resistance and increased risk for recurrence in patients with triple-negative breast cancer. Ann Oncol 19: 669-674, 2008. 